\title{
A Dynamic Typology of Informal Institutions: Learning from the Case of Guanxi
}

\author{
Sven Horak ${ }^{1}$ and Katja Restel ${ }^{2}$ \\ ${ }^{1}$ St. Fohn's University, USA, and ${ }^{2}$ University of Duisburg-Essen, Germany
}

ABSTRACT Currently, the mechanism in which informal institutions, recently discovered as an influential, new paradigm in business and management studies interact with and shape formal institutions remains unclear. Helmke and Levitsky (2004) proposed an outcome-based typology for the interaction of informal institutions with formal ones. By using a structured approach for literature aggregation, we test the proposed typology of Helmke and Levitsky by applying this method to 74 empirical studies to investigate the influence of guanxi on formal institutions. We conclude that guanxi fits into none of the proposed categories perfectly. As a result, we propose the relationship between guanxi and formal institutions as auxiliary as well as competing concurrently, leading to convergent and divergent outcomes, respectively. Moreover, we propose a third category to add to the existing typology, namely 'formal institutions in transition'. We furthermore incorporate a dynamic aspect to the model by adding two further categories, concerned with the direction of the development. We believe the resulting extension to the original typology of Helmke and Levitsky accurately accounts for the dynamic nature of informal institutions as well as their important role in shaping effective formal institutions.

KEYworDs China, guanxi, Helmke and Levitsky, informal institutions, institutional typology

\section{INTRODUGTION}

Informal institutions represent a new research agenda in business and management studies (Peng, Wang, \& Jiang, 2008). Whereas formal institutions, such as laws and regulations, remain relatively easy to frame and analyze due to their transparent, accessible and to some degree quantifiable nature, informal institutions, such as values, customs and norms of behavior, and informal networks represent a challenge (Wang, 2000). Their interference in and influence on business, managerial activities, and economic development have been regarded as tremendous (Lew, 2013; Meyer \& Peng, 2005; North, 1990; Ostrom, 1997). Formal and informal institutions interact and thus determine the effectiveness of one another (North, 
1990; Pejovich, 1999). Not only are international institutions concerned with economic development but also how informal institutions influence the effectiveness of formal institutions in terms of political and economical development. Multinational corporations, as well, need a better understanding of how informal institutions must be considered in order to successfully do business in local markets.

Several scholars raised fundamental, yet unanswered, questions: for example, what are informal institutions and why people give preference to them even over formal institutions with different intensities in different countries. In a widely cited study, Helmke and Levitsky (2004) aim to clarify why people feel inclined to create informal rules, even though a set of formal rules and legislation mechanisms already exist. According to these authors, three motivational reasons persist. First, people create informal rules because formal institutions are inefficient or fragmentary. Second, informal institutions can pose only a second-best strategy for the actors who are not able to locate an adequate formal institutional solution even though they would prefer to do so. In some cases, actors lack the potential to alter the existing formal rules; in other cases, actors create informal institutions because this is perceived as the cheaper alternative to designing a formal institution to suit their needs. The fabrication of informal institutions can also represent a second-best strategy when formal facilities exist on paper only and are ineffective in praxis. A third motivation develops from the intention to pursue socially unacceptable goals. Because informal organs possess a tendency for obscurity, they give the relevant actors the opportunity to create an agenda that would not withstand public scrutiny. Even in certain areas of the world where bribery, patrimonialism, and the buying of votes are accepted as a part of everyday life the universal rules foreclose their legalization (Helmke \& Levitsky, 2004).

The purpose of this study is twofold. First and foremost it seeks to further develop the widely accredited typology of institutional interaction proposed by Helmke and Levitsky using the example of guanxi. Helmke and Levitsky propose a structured outcome-based typology in order to shed light on how informal institutions interact with formal ones. This typology features an outcome-based model on how informal institutions interact with effective and ineffective formal institutions. However, this static element is incapable of capturing the dynamic nature of informal institutions. In addition it distinguishes effective and ineffective formal institutions only and ignores any intermediate state that formal institutions can assume. In this study, we test this typology, described in detail in the following section, against Chinese guanxi, an informal institution often regarded as interfering in China's institutional development. Building on the work of other guanxi scholars (e.g. Li, 2005, 2007a), we believe that important lessons can be learned to foster a better understanding of the interaction of formal and informal institutions. Second, in connection to the prior purpose of our research, this study contributes to the ongoing debate on how informal institutions can affect and shape the dynamic development of formal institutions in the latter's transitional process. 
The remainder of this study is organized as follows. We provide an explanation of the theoretical background in reference to the typology proposed by Helmke and Levitsky followed by a reflection on how guanxi might fit into this typology. Concerns about this connection are raised in a separate section on typological dissonance. Then, the empirical method, the stylized facts method (SFM), and corresponding process steps are explained and applied in order to aggregate the existing research results. Before summarizing what has been studied and delivering a conclusion, we report on limitations and future directions for research.

\section{THEORETIGAL BACKGROUND}

\section{Institutions: Definition, Interaction, and Co-evolution}

Institutions are traditionally defined as rules and procedures shaping social interaction by limiting and enabling the actions and behavior of subjects and individuals (North, 1990). Institutions may be categorized as formal and informal. Formal institutions are represented by the rule of law, courts, and bureaucracies while shaped, communicated, and implemented through official channels. This kind of institution can only enfold its bond force with the help of formal sanctions and usually occurs in writing. Informal institutions are, contrary to formal institutions, mostly unwritten and constructed, shared, and enforced outside of official channels. Many 'rules of the game', which structure politics as well as economics, are in fact informal. In this paper we employ the definition of informal institutions as used by Helmke \& Levitsky (2004) since we try to expand their model, thus treating informal institutions and norms synonymously.

$\mathrm{Li}$ identifies five dimensions of formality and informality (Li, 2005) and states that informality belongs in the scope of social ontology such as social ties and exchange events, which are 'implicitly assumed, endogenously formed and flexibly enforced by horizontal peers in a personalized process', (Li, 2007b: 6). The performance of formal institutions is crucially shaped and influenced by informal structures in an important and partially unpredictable way: however, there have been some attempts to unravel this connection (Helmke \& Levitsky, 2004; Lauth, 2000).

Institutional interaction and resulting co-evolution is a challenging theme. Given a lack of empirical studies, the nature and operating modes of the linkages between informal and formal institutions, their interaction and influence on each other's developmental direction is an important, yet poorly understood field of study (Hodgson, 2002). By nature, informal institutions are multidimensional: thus difficult to extract and analyze separately and also difficult to quantify (Ostrom, 1990, 2008). However, this field can reflect on a certain history of research. Early sociological inquiry (e.g., Coleman, 1966) started criticizing the view to regard existing social structures as given by analyzing how common decisions (or in other words formal institutions) are made and how they change (by e.g. informal institutions) over time. Further important attempts to bridge behavior on the 
micro-level to macro-level of institutions were completed by Granovetter (1973) who analyzed the strength of social ties between groups with linkage to information flow and community organization at the macro-level. Plowman, Baker, Beck, Kulkami, Solansky, and Travis (2007) extend change theory by observing changes in a church community and its environment when the decision was made to serve meals to homeless. This simple decision resulted in radical and continuous change that led to large and unplanned organizational transformations taking place in an evolutionary way between social structures and individual behavior. Often regarded as given and persisting, scholars have argued in the past that formal institutions, e.g. legal law, can be sometimes ineffective and subvert social cooperation (Fuller, 1981; Taylor, 1982). Social capital literature (e.g., Bourdieu, 1986; Coleman, 1988) has provided a forum for an enhanced understanding of the link of social connections and institutional change. Social capital, i.e. the sum of links established on trust, trustworthiness and reciprocity between individuals and groups can mobilize the process of institutional change, especially when formal institutions are impractical, improper, i.e. if they do not fit the environment and do not help individuals to solve their problems and are weakly monitored or their breach weakly (formally or informally) sanctioned (Ahn \& Ostrom, 2008; Ostrom, 1990). In the process of change the role of (informally) organized groups becomes pivotal (Nostrum, 1992; Ostrom, 2008). In terms of effectiveness, both types of groups, either small or large ones, can be as effective as the other (Esteban \& Rey, 2001; Olson, 1965). At a more mature stage of the change process, groups can trigger a movement targeted at changing formal institutions, as illustrated by McCarthy (1987) by means of the pro-life and pro-choice movement.

Whereas the Helmke and Levitsky typology tries to explain the forces leading to institutional interaction we try to shed more light into analyzing the outcome by using the special case of guanxi.

\section{A Typology of Institutions}

Until recently, the relation between formal and informal institutions has been classified into two categories; some scholars regard informal institutions as functional and problem solving (Axelrod, 1986) and some as dysfunctional and problem creating (Collins, 2002). Helmke and Levitsky (2004) expand the work of Lauth (2000), who distinguishes between three types of formal-informal institutional relationships (complementary, substitutive and conflicting) but neglects to go into further detail. Li (2007a) further elaborates on the aspect of strength for the abovementioned informal ties (social capital) and their respective influence on formal institutions. However, this is an aspect we chose to neglect in this context: our chosen research method cannot measure such facets. The typology of Helmke and Levitsky combines two dimensions (see Table 1).

The first dimension is concerned with the degree of the convergence of the outcomes produced by formal as well as informal institutions. The second dimension 
Table 1. A typology of informal institutions

\begin{tabular}{lll}
\hline \hline Outcomes & Effective formal institutions & Ineffective formal institutions \\
\hline Convergent & Complementary & Substitutive \\
Divergent & Accommodating & Competing \\
\hline \hline
\end{tabular}

Source: Helmke and Levitsky (2004: 728)

deals with the effectiveness of formal institutions. Effectiveness, in this case, means the extent to which written/formal rules are implemented and obeyed in practice.

Complementary implies that informal institutions co-exist with the existing formal institutions and entails that actors follow the written rules. This kind of informal institution fills gaps, takes care of issues the formal institutions neglect to deal with and thus enhances their efficiency (Lauth, 2000).

Accommodating combines effective formal institutions but divergent results. In this case, informal institutions create incentives for behavior that modifies the substantial effect of formal rules but does not directly violate them. They may be contradictory to the spirit of formal rules but not their writings. Even though this kind of informal institution is not necessarily efficiency enhancing, it is nevertheless able to strengthen the stability of a formal institution by cushioning demands for changes. The practice of blat utilized in the former Soviet Union provides an example of accommodating informal institutions. Because of strict rules, which prevented people meeting their basic needs, blat was used in order to meet these goals and also supported the existing regime because it cushioned demands for change (Ledeneva, 1998).

In the other two cases of the table, ineffective formal institutions are coupled with informal ones. In such cases formal rules and policies are not accentuated, which enables actors to ignore or violate them. Competing combines ineffective formal rules and divergent results and thus produces competing informal institutions. This category of informal institutions structures its incentives in an incompatible manner with formal rules: in order to obey one rule, one has to violate another.

Similar to the case of complementary institutions, substitutive informal institutions aim toward the achievement of results that are compatible with formal rules and procedures. This kind of informal institution exists in an environment in which formal institutions are not routinely enforced. Thus, they are in charge of accomplishing the issues of which formal institutions are incapable. In his work, Li (2006) also elaborates on these categories and labels them as either substituting or supplementing (when informal institutions meet effective formal ones) or suppressing or sabotaging.

By extending the widely recognized general typology of institutional interaction provided by Helmke and Levitzky, research started drawing attention to this important facet of institutional interaction and co-evolution in China. On the positive side, guanxi can be a competitive advantage for a firm in order to sustain frequent changes in the business environment due to technological advancement and globalization leading to hypercompetition (D'Aveni, 1994). In this effect firms 
need dynamic capabilities and guanxi can serve as a crucial asset in this juncture (e.g. Eisenhardt \& Martin, 2000; in more detail, see Li, 2007a, 2007b). However, when trying to get a better grasp on the widespread phenomenon of corruption, Li (2005, 2007a, 2007b) assumes that guanxi can also suppress or sabotage formal institutions and therewith promote corruption.

\section{Guanxi}

Guanxi is a uniquely Chinese concept embedded in the context of rather weak formal institutions and strong (informal) social ties (Li, 2007b). However, one has to be cautious not to mix guanxi with the Western idea of social capital. Whereas the latter 'refers to a group-based social tie, either weakly instrumental or weakly sentimental, but largely depersonalized and primarily non-kinship-based', a 'typical social tie in the East, Guanxi is a dyadic social tie, both sentimental and instrumental, strongly personalized, kinship- or non-kinship-based' (Li, 2012: 853). Guanxi is a system of favors (renqing), where mutual obligation and reciprocity is formed and the time for repayment flexible (Gold, Wank, \& Guthrie, 2002).

Guanxi is regarded as an important factor of influence in China's social cohesion; hence, it is equally important in economic activities (Chen, Chen, \& Huang, 2013; Li, 2007a, 2007b; Luo, 2007). Rather simply defined, it describes the relationship between objects, forces, and people (Yang, 1994). Pye (1982) defines guanxi as friendship with implications of the continued exchange of favors. The Confucian norm of reciprocity, as well as the focus on family and kinship, is expressed in the practice of guanxi. Guanxi implies a mutual obligation between two or more subjects. If one receives a favor from someone, it is expected of him or her to return a favor when asked for it.

Historically, guanxi provided welfare and took care of the social as well as material needs that formal institutions were unable to provide (Fan, 2002a). In 1951, Weber asserted that in China a lack of obligation existed towards political, ideological, or other impersonal groups. Therefore, unsurprisingly, guanxi institutions survived throughout centuries, filling the gaps of formal institutions and became an integral part of the Chinese social system. Guanxi can be used as a substitute for a reliable government and when an established rule of law is lacking (Xin \& Pearce, 1996). Weber also mentions that Western capitalism has been the root of the development of formal structures (1930). This can be observed in China since the government's decision to proceed with economic transition. In order to improve conditions for foreign investors, formal institutions are constructed and strengthened. Guanxi is also long-term-oriented and serves as a mechanism to stabilize social and economic relations. Estimates show every Chinese national belongs to at least one guanxi network.

Every story contains two sides; therein guanxi must also include negative characteristics. Owing to the immense trust between the members of a guanxi network, a safe environment arises for illegal transactions in a rather low-trust 
environment. The character of guanxi changed after the economic transition. Due to increased possibilities for corruption, often observed when new formal institutions are introduced into countries in transition (Zhan, 2012), guanxi was widely used for illegal and rent-seeking purposes. This situation resulted from government officials with excessive power, but little money, and the formation of a new class of businesspeople that lacked power but had ample funds (Ledeneva, 2008; Taube \& Schramm, 2003). However, while the Chinese economy prospers, there are detectable cultural changes (Leung, 2008), which, without doubt, also reflect on the institution of guanxi networks.

According to Li (2007b) guanxi plays a dual role as a specific event as well as an informal institution. In this context, however, we decide to treat guanxi first and foremost as an institution in accordance to the definition by Wang (2000) and other various scholars (e.g., Chen \& Chen, 2004; Guthrie, 1998; Pye, 1995).

To better understand guanxi's dual character, in reference to its negative and positive effects outlined above, one must understand the 'paradox' (Fang, 2012) of its immanent integration ability of both forces. In a Chinese context, this paradox is explained by an ancient, indigenous Chinese philosophy of yin yang (Chen, 2002; $\mathrm{Li}, 1998,2008$ ) and a central theme in Taoism. According to the yin yang view, a phenomenon has two opposing elements that are dependent on each other in order to be complete. Both opposing elements mutually transform and balance each other under different conditions. They mutually affirm and negate each other in unity ( $\mathrm{Li}, 2008)$.

Hence, from a yin yang point of view, contradicting positions are natural, nonparadoxical (i.e., the West often attaches a negative connotation to the word 'paradox': Fang, 2012) not mutually exclusive, but rather mutually dependent and necessary. Fin Yang is a force that synthesizes and harmonizes opposites, aiming at balancing contradictions (Fang, 2003, 2012; Li, 2012).

Understanding contradictory dynamics is a major research theme in the recent paradox debate (Beech, Burn, de Caestecker, MacIntosh, \& MacLean, 2004; Lewis, 2000) that is so far, curiously, discussed in parallel to the yin yang debate with less adaptation of the yin yang lens on phenomena (exceptions are, e.g. Chen, 2002, 2008). Just recently, an increasing number of scholars investigated the question in relation to how actors accept paradoxes and consequently deal with them (Jay, 2013; Smith \& Lewis, 2011).

However, whereas the paradox-scholars generally perceive the amalgamation of contradictory elements a 'paradox' that appears absurd, irrational or illogical; the yin yang worldview has potential to provide an answer and contribute to the debate by 'synthesizing' the connection between contradictions (Chen, 2002, 2008; Li, 2008).

\section{Typological Dissonance}

Helmke and Levitsky (2004) place the activities of rural Chinese temples and lineage associations to achieve a better distribution of goods (classifiable as guanxi) into the 
category of substitutive informal institutions. They argue that this kind of informal institution serves as a means to circumvent the inability of formal institutions to provide certain goods, such as social welfare. Formal institutions in China are by no means fully effective (yet), and guanxi remains a way to achieve goals (via legal or illegal routes) in order to overcome the voids left by formal institutions. However, with the spread of capitalism in China and the influx of more foreign investors, there will be an urgent need for effective formal institutions. Therefore, the likely outcome will push ineffective formal institutions to work toward higher effectiveness. The transition, or rather change, of formal institutions is by no means one-directional. Informal institutions are not limited to an enhancing effect, but can also harm the stability and effectiveness of formal institutions by giving strong incentives for rule-breaking behavior. There is even the possibility that a formal institution never reaches a state of effectiveness and may remain in a limbo between the two opposite efficiency outcomes, or that a formerly effective formal institution turns ineffective due to strong informal forces, owing to the concept of dynamic duality introduced by Fang (2012).

Underdeveloped formal institutions often characterize emerging economies such as China. This can result in an unstable environment and creates a void, which is then usually filled by informal institutions (Xin \& Pearce, 1996) during transitional phases. However, those informal institutions don't vanish once formal institutions are fully established. A duality situation occurs; the other one cannot fully exist without the other. This ideal proposed by Fang stated that 'potential paradox values coexist in any culture and they give rise to, exist within, reinforce, and complement each other to shape the holistic, dynamic and dialectical nature of culture' (Fang, 2012: 20).

Even though this article focuses on the informal norm of guanxi, this model aims at providing further distinctions to the relation between formal and informal institutions in general.

We argue that Helmke and Levitsky's typology of informal institutions neglected two important dimensions that reflect the reality of several countries in transition, not China exclusively. First, informal institutions are dynamic constructs that change in nature and influence over time. A sign of dynamism is provided by the interaction between formal and informal institutions, i.e. informal institutions influence formal institutions and vice versa (Posner, 1998). By developing an interaction thesis, Pejovich (1999) argues that new contractual arrangements are sought once economic conditions change for the betterment of individuals. By creating formal institutions, transaction costs can be reduced; hence, an incentive emerges to establish new rules formally, which, however, need to be in line with existing informal institutions (Pejovich, 1999). A stable and growing environment would not lead to the emergence of or demand for contractual agreements.

$\mathrm{Li}$ (2007b) states the current form and influence of guanxi is the result of historical interactions between formal and informal institutions. The rational-cognitive shade of guanxi is caused by the previously weak formal institutional environment and 
Table 2. Potential typological extension - 'Developing formal institutions'

\begin{tabular}{llll}
\hline \hline Outcomes & Effective formal institutions & Formal institutions in transition & Ineffective formal institutions \\
\hline Convergent & Complementary & $?$ & Substitutive \\
Divergent & Accommodating & $?$ & Competing \\
\hline \hline
\end{tabular}

Source: Adapted from Helmke and Levitsky (2004: 728)

pronounced moral-norm or emotional-affective side of guanxi, stemming from strong informal institutions due to the focus on familism as a Confucian heritage while aiming to counteract the abuse of state power.

Second, Helmke and Levitsky's typology only distinguishes between effective and ineffective formal institutions. Scholars studying developments in emerging economies typically observe an institutional transition phase (e.g., Peng \& Zhou, 2005; Peng, 2003; Taube, 2013). Zhan (2012) reports that countries in institutional transition are often prone to corruption as (newly introduced) formal institutions operate ineffectively at the beginning. Qian (1999) argues that imported or 'best practice' formal institutions are at risk of never becoming fully effective, as they need to be compatible with domestic informal institutions. Peng (2003) recognized institutions in transition by analyzing how firms make strategic decisions in a developing institutional environment. This research extends the strategic choice literature that has mostly analyzed a firm's behavior in stable or rather non-dynamic institutional environments.

Based on the above, we assume that formal institutions are seldom completely effective or completely ineffective, particularly in nations undergoing a state of transition, be it due to economic factors or political unrest triggered by revolution. Particularly, in developing countries or nations in transition, newly established formal institutions often need time and require modifications in order to become more effective. Thus, we propose adding a category to Helmke and Levitsky's typology that takes better accounts for countries in transition phases (see Table 2). In order to accommodate the aspect of change due to time and other factors, we also include two dynamic elements to the model, filling the gap between the definite stages.

Therefore, the question arises: how does guanxi interact with developing formal institutions? Is this different to its impact on effective and ineffective formal institutions? In the remainder, we outline how we approach this research question by choosing the Stylized Facts Method (SFM) as the empirical instrument for the aggregation of the empirical studies.

\section{METHOD}

\section{The SFM}

In order to explore our research question, we apply the SFM as an empirical instrument. The advantage of the SFM is that it takes a wider range of research 


\begin{tabular}{|c|c|c|c|c|}
\hline $\begin{array}{l}\text { Conceptual } \\
\text { framing }\end{array}$ & Research & $\begin{array}{l}\text { Statements } \\
\text { collection }\end{array}$ & Clustering & $\begin{array}{l}\text { Stylized } \\
\text { Facts }\end{array}$ \\
\hline $\begin{array}{l}\text { Step 1: } \\
\text { Definition of } \\
\text { the object of } \\
\text { investigation }\end{array}$ & $\begin{array}{l}\text { Step 2: } \\
\text { Literature } \\
\text { research }\end{array}$ & $\begin{array}{l}\text { Step 3: } \\
\text { Extraction of } \\
\text { research } \\
\text { results }\end{array}$ & $\begin{array}{l}\text { Step 4: } \\
\text { Grouping of } \\
\text { similar results }\end{array}$ & $\begin{array}{l}\text { Step 5: } \\
\text { Generalizing } \\
\text { clusters }\end{array}$ \\
\hline
\end{tabular}

Figure 1. Generating Stylized Facts - Process flow

results into account. Compared with a meta-analysis, the SFM is not limited to quantitative-oriented research; it can also take qualitative studies into account (Heine, Meyer, \& Strangfeld, 2005; Weißenberger \& Löhr, 2007). The SFM was originally applied by Kaldor (1968), in the field of empirical macroeconomic research in order to aggregate knowledge in a defined area by applying a structured approach. Contrary to some research that uses ad-hoc stylized facts for claims about the state of research, hence running the risk of being biased by the researcher's very own perception, Kaldor's intention was to offer a transparent and structured method of inquiry in order to reduce bias. The basic problem Kaldor tried so solve was to reduce the complexity of the empirical research results in a certain field by clustering and aggregating the state of research to allow a summarization based on a structured and transparent approach. Therewith, clusters of knowledge can be revealed that are more generally applicable to patterns of different observations as to negligible details. Applying the SFM can also be simply described as a summary of the knowledge of each defined subject area (Schwerin, 2001: 103).

\section{Process Description}

The process of deriving stylized facts is an inductive approach that aims to make generalized statements about a phenomenon. Based on the Heine et al. (2005) approach proposed herein, a process flow is performed, as shown in Figure 1.

The advantage of this approach is seen in the transparency of the results of individual steps. A constructive discussion of the partial results is possible as the generalization of recognizable patterns can be classified as subjective while still allowing a transparent approach that is easily traceable in each process step.

In the first step, a precise framing of the phenomenon under investigation is required. Here, it is important to decide which context to include or exclude or whether context doesn't matter. The following literature research should ideally focus on scholarly contributions published in academic outlets. Following the chosen level of abstraction in the first step, relevant statements (citations) from the selected sources are extracted in the third step. In a further step, similar statements are now a core term associated with clusters, which are based on the study phenomenon. Then, the statements are reduced to their implications. By neglecting irrelevant 
details, formerly decided by which context to be considered and which not, the data is aggregated and implications of the findings lead into the final step to generalized stylized facts.

\section{Literature Selection}

By applying a keyword research (keywords: guanxi, economics, business, management, interaction, formal, informal, institution) using the search engines and databases Google Scholar, EconLit, Web of Science, Emerald Full Text, Business Source Complete, International Bibliography of the Social Sciences (IBSS) and Scobus, we identified, as a first step, 104 relevant studies. In order to be considered for the extraction of research results (SFM step 3), we analyzed the papers to assess whether they contain any research results on the nature and influence of guanxi in China today, particularly their impact on formal institutions. Once identified, the citations of the relevant parts were extracted. In total, two scholars and two research assistants worked on this task. As a result, 30 studies were excluded from further investigation, as they showed no direct link to the research subject. The remaining 74 studies were considered for further analysis (steps 4 and 5).

\section{Evaluation of the Empirical Studies and Findings}

By performing a literature aggregation through following the process described in Figure 1, we clearly find large support in terms of the substitutive as well as competing nature of guanxi with ineffective formal institutions, leading to a convergent and divergent outcome respectively, as proposed by Helmke and Levitsky. However, several studies, specifically those published after 2000, are rather difficult to clearly allocate to the proposed typology. During the process we observed that it was quite difficult to clearly characterize guanxi as substitutive in its interaction with developing formal institutions. As a result of the competing nature of guanxi to developing formal institutions leading to convergent outcomes, we find several studies that regard guanxi as a persistent force with a changing nature that exists and takes effect along institutional development. However, we also need to keep in mind that the effect of guanxi competing with the developing formal institutions can also be classified as suppressing for they actively hinder their development towards full effectiveness. We thus chose to go with the definition as suggested by Li (2005). In the category of developing institutions, we propose considering the positive effect guanxi can have on developing formal institutions. Based on the literature, a facet of guanxi can be characterized as auxiliary to developing formal institutions, leading to convergent outcomes. We chose to label this category 'auxiliary' since our research clearly speaks for the assisting nature of guanxi with regard to the stability and effectiveness of developing formal institutions. A summary of the stylized facts analysis conducted is presented in Table 3. 
Table 3. Characterization of guanxi between 1993 and 2011

\begin{tabular}{|c|c|c|c|}
\hline Stylized Fact & Publication year & Author & Representative citation \\
\hline Substitutive & $\begin{array}{l}1993,1995, \\
1996,1997, \\
1998,2000 \\
2001,2002 \\
2003,2004, \\
2006,2007 \\
2007,2011\end{array}$ & $\begin{array}{l}\text { Smart, A. (1993); Pye, L.W. (1995); } \\
\text { Xin, K. R. (1996); Yeung, Y. M. I. } \\
\text { (1996); Bian, Y. (1997); Tsui, A. S. } \\
\text { (1997); Tsang, E. W. K. (1998); } \\
\text { Lee, M. Y., Paul, E. (2000); Pearce, } \\
\text { J. A. (2000); Dunfee,T. W. (2001); } \\
\text { Park, S. H. (2001); Leung, T. K. P. } \\
\text { (2001); Chan, R. Y. K. (2002); } \\
\text { Hitt, M. (2002); Ledeneva, A. V. } \\
\text { (2003); Su, C. (2003); Warren, D. } \\
\text { E., \& Dunfee, T. W. (2004); Zhang, } \\
\text { Y., \& Zhang, Z. (2006); Dunning, } \\
\text { J. H., \& Kim, C. (2007); Su, C., } \\
\text { Mitchell, R. K., \& Sirgy, M.J. } \\
\text { (2007); Lu, R., \& Reve, T. (201 1). }\end{array}$ & $\begin{array}{l}\text { 'Considered from this perspective, } \\
\text { the transaction-supporting } \\
\text { function of guanxi may be seen } \\
\text { as a viable alternative to formal } \\
\text { institutional support'. (Lee. M. } \\
\text { Y., 2000: 26). }\end{array}$ \\
\hline Competing & $\begin{array}{l}1995,1998 \\
2002,2003 \\
2004,2006 \\
2007,2008 \\
2010,2011\end{array}$ & $\begin{array}{l}\text { Davies, H. (1995); Farh, J. L. (1998); } \\
\text { Kiong, C. H. T. (1998); Fan, Y. } \\
\text { (2002); Yang, M. (2002); } \\
\text { Ledeneva, A. V. (2003); Chen, C., } \\
\text { Chen, Y., \& Xin, K. (2004); } \\
\text { Warren, D. E. (2004); Ai, J. (2006); } \\
\text { Zhang, Y., \& Zhang, Z. (2006); } \\
\text { Lee, E. Y., \& Anderson, A. R. } \\
\text { (2007); Li, P. P. (2005, 2007a, } \\
\text { 2007b); Wang, C. L. (2007); Gu, } \\
\text { F., Hung, K., \& Tse, D. (2008); } \\
\text { Hung, H. (2007); Ledeneva, A. } \\
\text { (2008); Provis, C. (2008); Ho, C., } \\
\text { \& Redfern, K. A. (2010); Chang, } \\
\text { K. (2011); Nie, R. et al. (2011). }\end{array}$ & $\begin{array}{l}\text { 'The weakness in the market } \\
\text { structure and an inadequate legal } \\
\text { system, combined with a lack of } \\
\text { transparency due to the absence } \\
\text { of political opposition and media } \\
\text { scrutiny, has allowed guanxi to } \\
\text { contribute greatly in making } \\
\text { China one of the most corrupted } \\
\text { countries in the world' (Fan } \\
\text { Ying, 2002: 378). }\end{array}$ \\
\hline Auxiliary & $\begin{array}{l}1995,2000, \\
2001,2003, \\
2004,2008, \\
2010,2011\end{array}$ & $\begin{array}{l}\text { Pye, L. W. (1995); Standifird, S. S. } \\
\text { (2000); Ledeneva, A. V. (2003); } \\
\text { Oh, H., Chung, M., \& Labianca } \\
\text { G. (2004); Li, P. P. (2005, 2007a, } \\
\text { 2007b); Lee, Pae, \& Wong (2001); } \\
\text { Anderson, A., Lee, E. Y. (2008); } \\
\text { Luo, Y., Huang Y., \& Wang, S. L. } \\
\text { (2011); Leung, T. K. P. et al. } \\
\text { (2011); Wilson G., \& Brennan, R. } \\
\text { (2010); Qin, Z. (2011); Chen, Z., } \\
\text { Huang, Y., \& Sternquist, B. (2011); } \\
\text { Chung, H. (2011); Guo, C., \& } \\
\text { Miller, J. K. (2010); Zolkiewski, J. } \\
\text { M., \& Feng, J. (2011). }\end{array}$ & $\begin{array}{l}\text { '. . guanxi will work in } \\
\text { conjunction with markets and } \\
\text { regulations, rather than as a } \\
\text { replacement'. (Anderson, A., } \\
\text { Lee, E.Y., 2008: 775). } \\
\text { 'The very pragmatic, utilitarian } \\
\text { character of guanxi can help it } \\
\text { to serve the function of } \\
\text { institutionalizing power } \\
\text { relationships, and thereby give } \\
\text { the system a degree of stability'. } \\
\text { (Pye L.W., 1995: 53). } \\
\text { 'Specifically, our meta-analysis } \\
\text { results demonstrate that both } \\
\text { business and government ties } \\
\text { lead to both economic and } \\
\text { operational performance'. (Luo, } \\
\text { Y., Huang, Y., Wang, S. L., } \\
2011 \text { : 139). }\end{array}$ \\
\hline
\end{tabular}


Auxiliary and convergent outcomes. As a result of our analysis we propose regarding guanxi a positive force that owing to the interaction with formal institutions can act as a vehicle toward a further degree of effectiveness of formal institutions.

Representative examples support our assumption, for instance, in the studies of Anderson and Lee (2008), who do not regard guanxi as a replacement for markets and regulations rather as complementary, and Pye (1995) who believes guanxi supports the institutionalization of power relationships and thereby contributes to system stability.

In addition, by considering the results of research in the field of what social capital can do to foster the development of more stable formal institutions, we see additional evidence that informal ties and networks contribute to the development of formal institutions, as the studies of Dasgupta (2000), Putnam (1993) and Coleman (1988) testify.

Suppressing and divergent outcome. On the contrary, we find evidence of the dual influence of guanxi during the transitional phase of formal institutional development. While guanxi can have an auxiliary influence on formal institutional development, it can concurrently compete with formal institutions, leading to divergent outcomes such as hampering formal institutional development, thus being of suppressive nature. The spread of corruption, often observed in transitional phases of institutional development (Zhan, 2012), can be regarded as a force competing with newly introduced formal institutions. In this case, the government can hardly control corruption, as it is often affected as well. In this relation, Hung (2007) notes that the Chinese government becomes increasingly less able to maintain control and discipline among its public officials. In summary, we distinguish two major characters of guanxi during the transitional phases of institutional development: auxiliary and suppressing.

Dynamic interaction. By taking the theories of institutional interaction into account (North, 1990; Pejovich, 1999; Stiglitz, 2001), we observe a two-way influence between formal and informal institutions. Briefly stated, informal institutions influence formal institutions and vice versa. How does that affect the influence of guanxi in terms of supporting the effectiveness of formal institutional development? This question remains difficult to answer based on current knowledge. An important aspect to consider is whether guanxi will in its current role, as facilitator of goods and services not easy to obtain via official channels, disappears or persists in the future. Li (2007b) summarizes the discourse on the fundamental guanxi base in which one camp of authors regard guanxi as deeply rooted in Chinese cultural values, whereas the other camp sees guanxi as influential due to the weak formal institutional environment. As a result, some foresee guanxi receding in the future, whereas others maintain the view that guanxi will persist (see Table 4).

Currently, scholars fail to agree whether the influence of guanxi should be regarded as cultural (i.e., as an argument toward persistence) or institutionally driven (i.e., 
Table 4. The influence of Guanxi-Receding, resilient, or dynamic?

\begin{tabular}{|c|c|c|c|}
\hline Stylized Fact & Publication year & Author & Representative citation \\
\hline Receding & $\begin{array}{l}1998,2002, \\
2003,2006, \\
2007,2008 \\
2010,2011\end{array}$ & $\begin{array}{l}\text { Guthrie, D. (1998); Fan, Y. (2002); } \\
\text { Ledeneva, A. V. (2003); } \\
\text { Hutchings, K., \& Weir, D. (2006); } \\
\text { Wang, G. L. (2007); Chang, K. } \\
\text { (201 1); Gu, F., Hung, K., \& Tse, } \\
\text { D. (2008); Wilson, G., \& Brennan, } \\
\text { R. (2010). }\end{array}$ & $\begin{array}{l}\text { 'With the strengthening of the } \\
\text { market and regulations, the role } \\
\text { of guanxi is diminishing'. } \\
\text { (Wilson G., Brennan, R., } \\
\text { 2010: 662). }\end{array}$ \\
\hline Resilient & $\begin{array}{l}2002,2006, \\
2007,2008, \\
2010,2011 \\
2012\end{array}$ & $\begin{array}{l}\text { Tan, D., \& Snell, R. S. (2002); Szeto, } \\
\text { R., Wright, P. C., \& Cheng, E. } \\
\text { (2006); Millington, A., Eberhardt, } \\
\text { M., \& Wilkinson B. (2006); } \\
\text { Anderson A., \& Lee, E. Y. (2008); } \\
\text { Wong, M., (2007); Gao, H., } \\
\text { Ballantyne, D., \& Knight, J. G. } \\
\text { (2010); Shou, Z. et al. (2011); } \\
\text { Zhang, J., \& Pimpa, N. (2010); } \\
\text { Zhuang, G., Xin, Y., \& Tsang, A. } \\
\text { (2010); Barnes, B., Yen, D., \& } \\
\text { Zhou, L. (201 1); Chen Y., } \\
\text { Friedman, R., Yu, E., \& Sun, F. } \\
\text { (2011); Li, J., \& Madsen, J. (2011); } \\
\text { Yen, D. A., \& Barnes, B. R., \& } \\
\text { Wang, C. L. (2011); Li, J. J., \& } \\
\text { Sheng, S. (2011); Luo, J. D. (2011); } \\
\text { Smith, P. B., Huang, H. J., Harb, } \\
\text { C., \& Torres, C. (2012). }\end{array}$ & $\begin{array}{l}\text { 'guanxi persists and may remain } \\
\text { essential in China' (Anderson, } \\
\text { A., Lee, E.Y., 2008: 775). }\end{array}$ \\
\hline Dynamism & $\begin{array}{l}1998,2002, \\
2003,2005 \\
2006,2008, \\
2010,2011\end{array}$ & $\begin{array}{l}\text { Guthrie, D. (1998); Ambler, T., } \\
\text { Styles, C., \& Wang, X. (1999); } \\
\text { Fan, Y. (2002); Ledeneva, A. V. } \\
\text { (2003); Lee, D. Y., \& Dawes, P. L., } \\
\text { (2005); Hutchings, K., \& Weir, D. } \\
\text { (2006); Szeto, R., Wright, P. C., \& } \\
\text { Cheng, E. (2006); Li, P. P. (2005, } \\
\text { 2007a, 2007b); Ledeneva, A. } \\
\text { (2008); Guo, C., \& Miller, J. K. } \\
\text { (2010); Lu, R., \& Ma, J. (2011), } \\
\text { Yang, Z., \& Wang, C. L. (2011). }\end{array}$ & $\begin{array}{l}\text { Although traditional practices (gift } \\
\text { or favour exchanges) still exist in } \\
\text { the Chinese business } \\
\text { environment, there is an emerging } \\
\text { new form of guanxi conduct } \\
\text { that involves knowledge and } \\
\text { information exchange'. (Guo, } \\
\text { C., Miller, J. K., 2010: 287). }\end{array}$ \\
\hline
\end{tabular}

as an argument toward receding). In the case of the former, guanxi may not recede quickly due to the rigid versatility of culture itself (Hofstede, 2007); in the case of the latter, it may change at the speed at which formal institutions gain stability (Peng et al., 2008). Along this ongoing debate, we see some recent support of a new alternative position that $\mathrm{Li}$ (2007b) names an integrated view of guanxi that is concurrently culturally, as well as institutionally, driven. The central question remains less about whether guanxi will persist or recede but rather how it will change in nature over the course of institutional development. Recent publications align with this integrated perspective. For instance, Guo and Miller (2010) see traditional facets of guanxi still applied in China (e.g. gift exchange) but point toward 
Table 5. The third category of formal institutions: 'formal institutions in transition'

\begin{tabular}{l|c|c|c}
\hline \hline \multirow{2}{*}{ Outcomes } & $\begin{array}{c}\text { Effective } \\
\text { formal institutions }\end{array}$ & $\begin{array}{c}\text { Formal institutions } \\
\text { in transition }\end{array}$ & $\begin{array}{c}\text { Ineffective } \\
\text { formal institutions }\end{array}$ \\
\hline \multirow{2}{*}{ Divergent } & Complementary & Auxiliary & Substitutive \\
\hline \hline
\end{tabular}

Source: Extension to Helmke and Levitsky (2004: 728)

new forms of guanxi that include the exchange of information and knowledge. Szeto et al. (2006) argue that today guanxi remains an important foundation for social capital but under the precondition that all relationships are built within a legal or ethical framework. Drawing conclusions from the ongoing debate proves difficult. However, independent of the views on guanxi as culturally or institutionally driven, support exists for the third view, namely the integrated perspective. Thus, we propose guanxi as a dynamic construct that can change its function and character during transitional phases.

\section{RESULTS}

\section{An Extension to the Gurrent Typology}

Based on the above, we propose an extension to the current typology from Helmke and Levitsky by including a third category of formal institution into the model, namely, due to its relation to time and dynamic process, 'formal institutions in transition', toward which guanxi acts as either auxiliary or suppressing, leading to convergent or divergent outcomes, respectively (see Table 5).

In the central time and dynamic process-influenced category, informal forces may be strong enough to push change forward or too weak to initiate a change of formal institutions. If in the course of this struggle a power-balance occurs, formal institutions may temporarily stay in the present state unless societal developments resume propulsive powers. In the category of ineffective formal institutions, the strong forces of (substitutive) informal institutions with convergent results make systems evolve, while with divergent outcomes, they strongly drive towards replacement or modification of the existing formal institutions (suppressing) due to environmental incompatibility. On the contrary, effective formal institutions will resist the change process and informal forces with convergent outcomes complement some changes. If the informal institutions have divergent results, then informal forces may be too weak or minor to change the system and finally become a part of the subculture (accommodating). 
In our argumentation, we characterize the category 'formal institutions in transition' as a central dynamic platform for institutions being ineffective, effective or maintain a transitional form if informal forces are neither stronger nor weaker to drive changes in either direction. Right now, China fits in this category rather well. We believe this category not only suits much better the situation of institutional development in emerging economies or economies in institutional transition, but also institutional developments in established economies can be better understood by including a dynamic category into the typology.

\section{DISGUSSION}

\section{Limitations and Future Research Directions}

The outcome of our investigation must be viewed within the confines of its limitations. To the best of our knowledge, this study represents the first attempt to extend the typology proposed by Helmke and Levitsky and thus should be considered a proposal to fertilize the ongoing discussion. Although we regard qualitative research as the best approach for advancing knowledge in this field, given the comprehensive set of existing empirical studies, qualitative research may not be suitable for exploration into subjects that lack scholarly interest so far, i.e. an insufficient number of studies to be analyzed. Further research might also highlight the issue of the dynamic of change with regard to the stability of a state, which could include the addition of further categories. However, in order to do so, a different tool must be employed since stylized facts analysis becomes inadequate.

Future research may test our proposed extension by using other examples. For instance, blat (Russia, e.g., Ledeneva, 2003, 1998), yongo (Korea, e.g., Horak, 2014; Lew, 2013; Yee, 2000a, 2000b) or wasta (Arabian world, e.g., Izraeli, 1997) would make excellent examples to test the proposed model, given, as stated above, a sufficient number of publications are available in these fields.

\section{GONCLUSION}

By applying the SFM, we tested the fit of guanxi as an example for informal institution against the proposed typology of Helmke and Levitsky. Our analysis led to three results. First, we regard guanxi as currently operating in a transitional environment. Though Helmke and Levitsky's typology proposes only two categories of formal institutions, namely effective and ineffective formal institutions, we suggest an extension by including a third category, formal institutions in transition, which takes real world dynamic developments better into account as institutions in all economies, either developed or emerging, are transforming at varying paces. Second, we find evidence, especially from newer research publications, demonstrating guanxi leads to two outcomes in an environment in which formal institutions are developing. On one hand, guanxi acts auxiliary to institutional 
development, leading to convergent outcomes; on the other, it acts competing and thus suppressing to institutional development, leading to divergent outcomes. Third, aside from the debate of whether guanxi is culturally rooted or rather institutionally driven, we see much evidence to regard guanxi as a dynamic construct in line with Li's (2007b) view, who proposed an integrated view of guanxi. In other words, guanxi will likely persist and continue to exert influence despite its morphing nature and character as the institutional environment develops.

We believe the proposed extended typology is especially beneficial to analyze dynamic institutional transition phases. Future research may apply and develop our model further by using examples like blat, yongo, or wasta, using qualitative analysis given a sufficient quantity of reliable empirical research.

\section{REFERENGES}

Ahn, T. K., \& Ostrom, E. 2008. Social capital and collective action. In D. Castiglione, J. van Denth, \& G. Wolleb (Eds.), The handbook of social capital: 70-100. Oxford: Oxford University Press.

Ai, J. 2006. Guanxi networks in China: Its importance and future trends. China \& World Economy, 14(5): 105-118.

Ambler, T. 1999. The effect of channel relationships and guanxi on the performance of inter-province export ventures in the People's Republic of China. International Journal of Research in Marketing, 16: 75-87.

Anderson, A., \& Lee, E. Y. 2008. From tradition to modern - attitudes and applications of guanxi in Chinese entrepreneurship. Journal of Small Business and Enterprise Development, 15(4): 775-787.

Axelrod, R. 1986. An evolutionary approach to norms. American Political Science Review, 80(4): 1095-1111.

Barnes, B., Yen, D., \& Zhou, L. 2011. Investigating guanxi dimensions and relationship outcomes: Insights from Sino-Anglo business relationships. Industrial Marketing Management, 40: $510-521$.

Beech, N., Burn, H., de Caestecker, L., MacIntosh, R., \& MacLean, D. 2004. Paradox as invitation to act in problematic change situations. Human Relations, 57(10): 1313-1332.

Bian, Y. 1997. Guanxi networks and job mobility in China and Singapore. Social Forces, 75(3): 981-1005.

Bourdieu, P. 1986. The forms of capital. In J. Richardson (Ed.), The handbook of theory and research for the sociology of education: 241-258. New York: Greenwood.

Chan, R. Y. K. 2002. The dynamics of guanxi and ethics for Chinese executives. Journal of Business Ethics, 41(4): 327-336.

Chang, K. 2011. A path to understanding guanxi in China's transitional economy: Variations on network behavior. Sociological Theory, 29(4): 315-340.

Chen, C. C., Chen, X. P., \& Huang, S. 2013. Chinese guanxi: An integrative review and new directions for future research. Management and Organization Review, 9(1): 167-207.

Chen, C., Chen, Y., \& Xin, K. 2004. Guanxi practices and trust in management: A procedural justice perspective. Organization Science, 15(2): 200-209.

Chen, M -J. 2002. Transcending paradox: The Chinese 'middle way' perspective. Asia Pacific Journal of Management, 19(2): 179-199.

Chen, M. -J. 2008. Reconceptualizing the competition-cooperation relationship: A transparadox perspective. Journal of Management Inquiry, 17(4): 288-304.

Chen, X., \& Chen, C. 2004. On the intricacies of the Chinese guanxi: A process model of guanxi development. Asia Pacific Journal of Management, 21(3): 305-324.

Chen, Y., Friedman, R., Yu, E., \& Sun, F. 2011. Examining the positive and negative effects of guanxi practices: A multi-level analysis of guanxi practices and procedural justice perceptions. Asia Pacific Journal of Management, 28: 715-735. 
Chen, Z., Huang, Y., \& Sternquist, B. 2011. Guanxi practice and Chinese buyer-supplier relationships: The buyer's perspective. Industrial Marketing Management, 40(4): 569-580.

Chung, H. 2011. Market orientation, guanxi and business performance. Industrial Marketing Management, 40(4): 522-533.

Coleman, J. S. 1966. Foundations for a theory of collective decisions. American Journal of Sociology, 71(6): 615-627.

Coleman, J. S. 1988. Social capital in the creation of human capital. American Journal of Sociology, 94: S95-S120.

Collins, K. 2002. Clans, pacts and politics in Central Asia.Journal of Democracy, 13(3): 137-152.

Dasgupta, P. 2000. Economic progress and the idea of social capital. In P. Dasgupta \& I. Seragelden (Eds.), Social capital: A multi-faceted perspective: 325-401. Washington, DC: World Bank.

D'Aveni, R.A. 1994. Hypercompetition: Managing the dynamics of strategic management. New York: The Free Press.

Davies, H. 1995. The value of relationships in developing the Chinese market. Industrial Marketing Management, 24: 207-214.

Dunfee, T. W. 2001. Is guanxi ethical? A normative analysis of doing business in China. Journal of Business Ethics, 32(3): 191-204.

Dunning, J. H., \& Kim, G. 2007. The cultural roots of guanxi: An exploratory study. World Economy, 30(2): 329-341.

Eisenhardt, K. M., \& Martin, J. A. 2000. Dynamic capabilities: What are they? Strategic Management Journal, 21(10-11): 1105-1121.

Esteban, J., \& Ray, D. 2001. Collective action and the group size paradox. American Political Science Revieze, 95(3): 663-672.

Fan, Y. 2002a. Questioning guanxi: Definition, classification and implications. International Business Revieze, 11(5): 543-561.

Fan, Y. 2002b. Guanxi's consequences: Personal gains at social cost. Journal of Business Ethics, 38(4): 371-380.

Fan, Y. 2007. Guanxi, Government and corporate reputation in China: Lessons for international companies. Marketing Intelligence and Planning, 25(5): 499-510.

Fang, T. 2003. A critique of Hofstede's fifth national culture dimension. International Journal of Cross Cultural Management, 3(3): 347-368.

Fang, T. 2012. Yin Yang: A new perspective on culture. Management and Organization Revieze, $8(1): 25-50$.

Farh, J. L. 1998. The influence of relational demography and guanxi: the Chinese case. Organization Science, 9(4): 471-488.

Fuller, L. 1981. The problem of social order. Durham, NC: Duke University Press.

Gao, H., Ballantyne, D., \& Knight, J. G. 2010. Paradoxes and guanxi dilemmas in emerging ChineseWestern intercultural relationships. Industrial Marketing Management, 39(2): 264-272.

Gold, T., Guthrie, , \& D. Wank, D. Eds. 2002. Social connections in China: Institutions, culture, and the changing nature of guanxi. Cambridge: Cambridge University Press.

Granovetter, M. S. 1973. The strength of weak ties. American Journal of Sociology, 78(6): 13601380.

Gu, F., Hung, K., \& Tse, D. 2008. When does guanxi matter? Issues of capitalization and its dark sides. Journal of Marketing, 72(4): 12-28.

Guo, C., \& Miller, J. K. 2010. Guanxi dynamics and entrepreneurial firm creation and development in China. Management and Organization Revieze, 6(2): 267-291.

Guthrie, D. 1998. The declining significance of guanxi in China's economic transition. The China Quarterly, 154: 254-282.

Helmke, G., \& Levitsky, S. 2004. Informal institutions and comparative politics: A research agenda. Perspectives on Politics, 2(4): 725-740.

Heine, B. O., Meyer, M., \& Strangfeld, O. 2005. Stylised facts and the contribution of simulation to the economic analysis of budgeting. Journal of Artificial Societies and Social Simulation, 8(4): 4 .

Hitt, M. A. 2002. The importance of social capital to the management of multinational enterprises: Relational networks among Asian and western firms. Asia Pacific Journal of Management, 19(2): 353-372.

Ho, C., \& Redfern, K. A. 2010. Consideration of the role of guanxi in the ethical judgments of Chinese managers. Journal of Business Ethics, 96(2): 207-221. 
Hodgson, G. M. 2002. The evolution of institutions: An agenda for future theoretical research. Constitutional Political Economy, 13(2): 111-127.

Hofstede, G. 2007. Asian management in the 21 st century. Asia Pacific Journal of Management, 24(4): 411-420.

Horak, S. 2014. Antecedents and characteristics of informal relation-based networks in Korea: Yongo, Yonjul and Inmaek. Asia Pacific Business Revieze, 20(1): 78-108.

Hung, H. 2007. Normalized collective corruption in a transitional economy: Small treasuries in large Chinese enterprises. Journal of Business Ethics, 79(1): 69-83.

Hutchings, K., \& Weir, D. 2006. Understanding networking in China and the Arab World: Lessons for international managers. Journal of European Industrial Training, 30(4): 272-290.

Izraeli, D. 1997. Business ethics in the Middle East.Journal of Business Ethics, 16(14): 1555-1560.

Jay, J. 2013. Navigating paradox as a mechanism of change and innovation in hybrid organizations. Academy of Management Journal, 56(1): 137-159.

Kaldor, N. 1968. Capital accumulation and economic growth. In F. Lutz and D. C. Hague (Eds.), The theory of capital: 177-222. London: Palgrave Macmillan.

Kiong, CH. T. 1998. Guanxi bases, Xinyong and Chinese business networks. The British Journal of Sociology, 49(1): 75-96.

Lauth, H. 2000. Informal institutions and democracy. Democratization, 7(4): 21-50.

Ledeneva, A. V. 1998. Russia's economy of favours: Blat, networking, and informal exchange. Cambridge: Cambridge University Press.

Ledeneva, A. V. 2003. Informal practices in changing societies: Comparing Chinese guanxi and Russian blat. London: Politics.

Ledeneva, A. V. 2008. Blat and guanxi: Informal practices in Russia and China. Comparative Studies in Society and History, 50(1): 118-144.

Lee, M. Y., \& Paul, E. 2000. Insider-outsider perspectives of guanxi. Business Horizons, 43(1): 25-30.

Lee, D. Y., \& Dawes, P. L. 2005. Guanxi, trust, and long-term orientation in Chinese business markets. Journal of International Marketing, 13(2): 28-56.

Lee, D. -J., Pae, J. H., \& Wong, Y. H. 2001. A model of close business relationships in China (guanxi). European Journal of Marketing, 35(1): 51-69.

Lee, E. Y., \& Anderson, A. R. 2007. The role of guanxi in Chinese entrepreneurship.Journal of Asia Entrepreneurship and Sustainability, 3(3): 38-51.

Leung, K. 2008. Chinese culture, modernization and international business. International Business Revieze, 17(2): 184-187.

Leung, T. K. P. 2001. The ethics and positioning of guanxi in China. Marketing Intelligence \& Planning, 19(1): 55-64.

Leung, T. K. P., Chan, R. Y., Lai, K., \& Ngai, E. W. T. 2011. An examination of the influence of guanxi and xinyong (utilization of personal trust) on negotiation outcome in China: An old friend approach. Industrial Marketing Management, 40(7): 1193-1205.

Lew, S. G. 2013. The Korean economic development path - Confucian tradition, affective network. New York: Palgrave Macmillan.

Lewis, M. 2000. Exploring paradox: Towards a more comprehensive guide. Academy of Management Revieze, 25(4): 760-776.

Li, J., \& Madsen, J. 2011. Business ethics and workplace 'guanxi' in Chinese SOEs: A qualitative study. Journal of Chinese Human Resource Management, 2(2): 83-99.

Li, J.J., \& Sheng, S. 2011. When does guanxi bolster or damage firm profitability? The contingent effects of firm- and market-level characteristics. Industrial Marketing Management, 40(4): $561-568$.

Li, P. P. 1998. Towards a geocentric framework of organizational form: A holistic, dynamic and paradoxical approach. Organization Studies, 19(5): 829-861.

Li, P. P. 2005. The puzzle of China's township-village enterprises: The paradox of local corporatism in a dual-track economic transition. Management and Organization Revieze, 1(2): 197-224.

Li, P. P. 2007a. Social tie, social capital, and social behavior: Toward an integrative model of informal exchange. Asia-Pacific Journal of Business Management, 24(2): 227-246.

Li, P. P. 2007b. Guanxi as the Chinese norm for personalized social capital: Toward an integrated duality framework of informal exchange. In H. W. Yeoung (Ed.), Handbook of research on Asian business: 62-83. Cheltenham, UK: Edward Elgar.

Li, P. P. 2008. Toward a geocentric framework of trust: An application to organizational trust. Management and Organization Reviez, 4(3): 413-439. 
Li, P. P. 2012. Toward an integrative framework of indigenous research: The geocentric implications of Yin-Yang Balance. Asia Pacific Journal of Management, 29(4): 849-872.

Luo, Y., Huang, Y., \& Wang, S. L. 2011. Guanxi and organizational performance: A meta-analysis. Management and Organization Revieze, 8(1): 139-172.

Luo, J. D. 2011. Guanxi revisited: An exploratory study of familiar ties in a Chinese workplace. Management and Organization Revieze, 7(2): 329-351.

Lu, R., \& Reve, T. 2011. Guanxi, structural hole and closure. Journal of Strategy and Management, 4(3): 275-288.

Lu, R., \& Ma, J. 2011. Can Western interorganizational governance mechanisms be applied to a guanxi based market? Asia-Pacific Journal of Business Administration, 3(2): 114-131.

Luo, Y. 2007. Guanxi and business. Singapore: World Scientific Publishing Company.

McCarthy, J. D. 1987. Pro-life and pro-choice mobilization: Infrastructure deficits and new technologies. In N. Mayer \& J. D. McCarthy (Eds.), Social movements in an organizational society: Collected essays: 49-66. New Jersey: New Brunswick.

Meyer, K., \& Peng, M. W. 2005. Probing theoretically into Central and Eastern Europe: Transactions, resources, and institutions. Journal of International Business Studies, 36: 600-621.

Millington, A., Eberhardt, M., \& Wilkinson, B. 2006. Guanxi and supplier search mechanisms in China. Human Relations, 59(4): 505-531.

Nie, R., Zhong, W., Zhou, M., Jiang, W., \& Wang, X. 2011. A bittersweet phenomenon: The internal structure, functional mechanism, and effect of guanxi on firm performance. Industrial Marketing Management, 40: 540-549.

North, D. 1990. Institutions, institutional change and economic performance. Cambridge: Cambridge University Press.

Nostrum, E. 1992. Crafting institutions for self-governing irrigation systems. San Francisco, CA: ICS Press.

Oh, H., Chung, M., \& Labianca, G. 2004. Group social capital and group effectiveness: The role of informal socializing ties. Academy of Management Journal, 47(6): 860-875.

Olson, M. 1965. The logic of collective action. Cambridge, MA: Harvard University Press.

Ostrom, E. 1990. Governing the commons: The evolution of institutions for collective action. New York: Cambridge University Press.

Ostrom, E. 1997. Capital, institutions, incentives. In C. Clague (Ed.), Institutions and economic development: Grozeth and governance in less-developed and postsocialist countries. Baltimore, MD: Johns Hopkins University Press.

Ostrom, E. 2008. Building trust to solve commons dilemmas: Taking small steps to test an evolving theory of collective action. In Levin, S. (Ed.), Games, groups, and the global good, 207-228. New York: Springer.

Park, S. H. 2001. Guanxi and organizational dynamics: Organizational networking in Chinese firms. Strategic Management Journal, 22(5): 455-477.

Pearce, G. A. 2000. Cultivating guanxi as a foreign investor strategy. Business Horizons, 43(1): 31-38.

Pejovich, S. 1999. Interaction of formal and informal institutions on social stability and economic development. Journal of Markets \& Morality, 2(2): 164-181.

Peng, M. W. 2003. Institutional transitions and strategic choices. Academy of Management Reviez, 28(2): 275-296.

Peng, M. W., \& Zhou, J. Q. 2005. How network strategies and institutional transitions evolve in Asia. Asia Pacific Journal of Management, 22(4): 321-336.

Peng, M. W., Wang, D. Y. L., \& Jiang, Y. 2008. An institution-based view of international business strategy: A focus on emerging economies.Journal of International Business Studies, 39(5): 920-936.

Peng, M. W., Sun, S. L., Pinkham, B., \& Chen, H. 2009. The institution-based view as a third leg for a strategy tripod. Academy of Management Perspectives, 23(4): 63-81.

Plowman, D. A., Baker, L. T., Beck, T. E., Kulkarni, M., Solansky, S. T., \& Travis, D. V. 2007. Radical change accidentally: The emergence and amplification of small change. Academy of Management Journal, 50(3): 515-543.

Posner, E. 1998. Symbols, signals, and social norms in politics and law. Journal of Legal Studies, 27(52): 765-797.

Provis, C. 2008. 'Guanxi' and conflict of interests. Journal of Business Ethics, 79(1-2): 57-68.

Putnam, R. D. 1993. Civic traditions in modern Italy. Princeton, NJ: Princeton University Press. 
Putnam, R., Leonardi, R., \& Nanetti, R. 1993. Making democracy work. Princeton, NJ: Princeton University Press.

Pye, L. 1982. Chinese commercial negotiating style. Santa Monica, CA: Rand.

Pye, L. W. 1995. Factions and the politics of guanxi: Paradoxes in Chinese administrative and political behavior. The China Journal, 34: 35-53.

Qian, Y. 1999. The institutional foundations of China's market transition (April 1999). Conference Paper, Annual Bank Conference on Development Economics, Washington, DC. Available from URL: http://ssrn.com/abstract=187568

Qin, Z. 2011 . Models of trust-sharing in Chinese private enterprises. Economic Modelling, 28(3): 1017-1029.

Schwerin, J. 2001. Wachstumsdynamik in transformationsökonomien. Böhlau: Köln.

Shou, Z., Guo, R., Zhang, Q., \& Su, C. 2011. The many faces of trust and guanxi behavior: Evidence from marketing channels in China. Industrial Marketing Management, 40(4): 503 509.

Smart, A. 1993. Gifts, bribes, and guanxi: A reconsideration of Bourdieu's social capital. Cultural Anthropology, 8(3): 388-408.

Smith, P. B., Huang, H.J., Harb, G., \& Torres, C. 2012. How distinctive are indigenous ways of achieving influence? A comparative study of guanxi, wasta, jeitinho, and 'pulling strings'.Journal of Cross-Cultural Psychology, 34(1): 135-150.

Smith, W. K., \& Lewis, M. W. 2011. Toward a theory of paradox: A dynamic equilibrium model of organizing. Academy of Management Revieze, 36(2): 381-403.

Standifird, S. S. 2000. The transaction cost advantage of guanxi-based business practices. Journal of World Business, 35(1): 21-42.

Stiglitz, J. E. 2001. Challenges in the analysis of the role of institutions in economic development. In G. Kochendörfer-Lucius \& B. Pleskovic (Eds.), The institutional foundations of a market economy. Berlin \& Washington, DC: German Foundation for International Development (DSE) \& World Bank.

$\mathrm{Su}, \mathrm{C}$. 2003. Is guanxi orientation bad, ethically speaking? A study of Chinese enterprises. Journal of Business Ethics, 44(4): 303-312.

Su, C., Mitchell, R. K., \& Sirgy, M. J. 2007. Enabling guanxi management in China: A hierarchical stakeholder model of effective guanxi. Journal of Business Ethics, 71(3): 301-319.

Szeto, R., Wright, P. G., \& Cheng, E. 2006. Business networking in the Chinese context: Its role in the formation of guanxi, social capital and ethical foundations. Management Research Neres, 29(7): 425-438.

Tan, D., \& Snell, R. S. 2002. The third eye: Exploring guanxi and relational morality in the workplace. Journal of Business Ethics, 41(4): 361-384.

Taube, M., \& Schramm, M. 2003. The institutional economics of legal institutions, guanxi, and corruption in the PR China. In J. Kidd and F. -J. Richter (Eds.), Fighting corruption in Asia. Causes, effects and remedies: 271-296. London: World Scientific Publishing Co.

Taube, M. 2013. Relational corruption in the PR China. Institutional foundations and its (Dys)functionality for economic development and growth. Comparative Governance and Politics, 7(1): 89-116.

Taylor, M. 1982. Community, anarchy, and liberty. Cambridge: Cambridge University Press.

Tsang, E. W. K. 1998. Can guanxi be a source of sustained competitive advantage for doing business in China? Academy of Management Executive, 12(2): 64-73.

Tsui, A. S. 1997. Where guanxi matters: relational demography and guanxi in the Chinese context. Work and Occupations, 24(1): 56-79.

Weber, M. 1930. The protestant ethic and the spirit of capitalism. London: Allen and Unwin.

Weber, M. 1951. The religion of China. New York: Free Press.

Wang, H. 2000. Informal institutions and foreign investment in China. Pacific Revieze, 13(4): $525-556$.

Wang, G. L. 2007. Guanxi vs. relationship marketing: Exploring underlying differences. Industrial Marketing Management, 36(1): 81-86.

Warren, D. E., Dunfee, T. W., \& Li, N. 2004. Social exchange in China: The double-edged sword of guanxi.Journal of Business Ethics, 55(4): 355-372.

Weißenberger, B. E., \& Löhr, B. 2007. Planung und Unternehmenserfolg: Stylized facts aus der empirischen Controllingforschung im deutschsprachigen Raum von 1990-2007. Zeitschrift für Planung \& Unternehmenssteuerung, 18(4): S335-363. 
Wilson, G., \& Brennan, R. 2010. Doing business in China: Is the importance of guanxi diminishing? European Business Review, 22(6): 652-665.

Wong, M. 2007. Guanxi and its role in business. Chinese Management Studies, 1(4): 257- 276.

Xin, K., \& Pearce, J. 1996. Guanxi: Connections as substitutes for formal institutional support. Academy of Management Journal, 39(6): 1641-1658.

Yang, M. 1994. Gifts, favors, and banquets: The art of social relationships in China. Ithaca, NY: Cornell University Press.

Yang, M. 2002. The resilience of guanxi and its new deployments: A critique of some new guanxi scholarship. The China Quarterly, 170: 459-476.

Yang, Z., \& Wang, G. L. 2011. Guanxi as a governance mechanism in business markets: Its characteristics, relevant theories, and future research directions. Industrial Marketing Management, 40: 492-495.

Yee, J. 2000a. The social networks of Koreans. Korea Journal, 40(1): 325-352.

Yee, J. 2000b. Too modern too soon? Dualism in civil society, everyday life, and social relations in contemporary Korea. Korea Journal, 40(1): 282-284.

Yen, D. A., Barnes, B. R., \& Wang, C. L. 2011. The measurement of guanxi: Introducing the GRX scale. Industrial Marketing Management, 40: 97-108.

Yeung, Y. M. I. 1996. Achieving business success in Confucian societies: The importance of guanxi (connections). Organizational Dynamics, 25(2): 54-65.

Zhan, J. V. 2012. Filling the gap of formal institutions: The effects of guanxi network on corruption in reform-era China. Crime Laze and Social Change, 58(2): 93-109.

Zhang, J., \& Pimpa, N. 2010. Embracing guanxi: The literature review. International Journal of Asian Business and Information Management, 1(1): 23-31.

Zhuang, G., Xin, Y., \& Tsang, A. 2010. Power, conflict and cooperation: The impact of guanxi in Chinese marketing channels. Industrial Marketing Management, 39: 137- 149.

Zhang, Y., \& Zhang, Z. 2006. Guanxi and organizational dynamics in China: A link between individual and organizational levels. Journal of Business Ethics, 67(4): 375-392.

Zolkiewski, J. M., \& Feng, J. 2011. Relationship portfolios and guanxi in Chinese business strategy. Journal of Business \& Industrial Marketing, 27 (1):16-28.

Sven Horak (horaks@stjohns.edu) is an assistant professor at The Peter J. Tobin College of Business of the St. John's University in New York City, where he researches and teaches in the area of international management. His research interests include the fundamental analysis of informal relation-based network structures, interpersonal relationships and social ties, managerial behavior, informal management, distinctive socio-cultural aspects of management and Asian business and management.

Katja Restel (Katjajr@gmx.de) holds a Master's degree in Social Sciences as well as in Contemporary East Asian Studies. She is a doctoral student at the Mercator School of Management at the University of Duisburg-Essen and currently works on her dissertation which is concerned with the influence of informal networks in Asian business and management in general and on Human Resource decisions in particular.

Manuscript received: $\quad$ March 02, 2014

Final version accepted: February 19, 2015 (numbers of revisions - 2)

Accepted by: Senior Editor Xueguang Zhou 